all the tadpole stages of metamorphosis while still in the egg. All these stages have been observed by M. Bavay; and whoever is familiar with the evolution of the ordinary tadpole before it quits the egg, will see that M. Bavay has observed only a modified form of the well-known process. The Guadeloupe frog is born as a frog, not as a tadpole; and this, paradoxical as it may seem to some naturalists who cannot dismiss traditional conceptions, is even less remarkable than the case of the Salamandra atra, because it is only an extension of the period of incubation, whereas with the salamander it is the substitution of viviparity for oviparity. How the presence of water leads to an acceleration of the birth, or the absence of water leads to its retardation, is an interesting point for investigation; whether retarded or accelerated, the finally-acquired structure is the same.

The Priory, March 22 George Henry Lewes

\section{Anticipations of Natural Philosophy MaUpertuis}

HAVING lately had occasion to examine the works of Maupertuis I, like Prof. Jevons, was struck by meeting with anticipatory glimpses of the modern theory of Natural Selection. The passage, given almost word for word by Lord Bolingbroke in the passage, given alio by Prof. Jevons, occurs somewhat incidentally in two parts of Maupertuis' writings ; in the memoir alluded to "Les Loix du Mouvement et du Repos, déduites d'un principe métaphysique"); and in the "Essay de Cosmologie," into which the memoir was expanded five years later $(1751)$. In both these works Maupertuis is chiefly concerned with establishing his well-known metaphysico-mechanical principle of "The Least Action " "La moindre Quantité d'Action"); and with deducing therefrom proof of the existence of God. But the doctrine of "The Survival of the Fittest" is more clearly discernible, and more than incidentally referred to, in his small physiological treatise, "Venus physique" (CEuvres, tome ii. ed. 1756). The whole of this work is not wanting in interest, but as bearing specially on the subject in question, I would mention the third, specially last chapters of the second part Chapte: III. is entiiled "Production de nouvelles especes." In it the most pronounced passage is perhaps the following: "Mais la sage Nature, par le dégoût qu'elle a inspiré pour ces défauts, n'a pas voulu qu'ils se perpetuassent; chaque père, chaque mère fait de son mieux pour les éteindre; les beautés sont plus sûrement héréditaires; la taille, et. la jambe, que nous admirons, sont héréditaires; la taille, é. lárations, où l'on s'est appliquè à les former" Chapter V., called an "Essay d'explication des phénomènes précédents," is an attempt to explain the physiophenomenes precedents, in the preservation of the best types, and in the production of new forms. On the efficacy of these processes the author says : "L'expérience pourroit, peut-être, processes the author s'on essayoit pendant longtemps de mutiler quelques animaux de génération en génération, peut-être verroiton les parties rétranchées, diminuer peu à peu; peut ètre on les pa les la fin s'anéantir." The last chapter contains a verroit-on les à la fin s'aneantir." The last chapter contains a summary of the whole work, author. In one of these he asks, "Cet instinct des animaux, qui leur fait rechercher ce qui leur convient, et fuir ce qui leur nuit, n'appartient-il point aux plus petites parties dont l'animal est formé?" In another question Maupertuis puts forward a bold hypothesis as to the influence which the decomposed material of the dead animal organism might exercise upon plants, and through them upon the structure and charactor of the living organism.

In his Systeme de la Nature also (CEuvres, tom. ii. ed. 1756), Maupertuis combats the special creation theory of the origin of species, and advocates a doctrine, which may be called Natural Selection, the selective principle being placed in the ultimate elements of both organic and inorganic substances, of which elements "la perception est une propriécé essentielle," and which "doués d'intelligence s'arrangent et s'unissent pour remplir les "vues du Créateur."

Such are a few of the glimpses to be met with in the French philosopher, of the modern doctrine of Darwin and Spencer. Similar ones may not improbably be found elsewhere, but such "resultless tendencies," as the course of events has proved them to be, can in no degree detract from the merit and originality of these who have made of Natural Selection a well-substantiated and homogeneous theory.

Crace's Koad, Camberwell, March Io
W. H. BREWER

\section{EMPEDOCles}

ON reading Prof. W. Stanley Jevons' interesting letter in this week's NATURE, I referred to my note-book, and found the following quotation, under the title of "Natural Selection," which shows that the opinion of Maupertuis is at least as old as Empedocles. - "Cette dernière opinion sert á expliquer les idées d'Empédocle sur la production des animaux par des causes accidentelles. L'attraction et la répulsion des élémens donnèrent naissance dans les commencemens et par le seul effet du hasard, à des têtes sans cou, à des jambes sans corps, à des animaux moitié boufs et moitié hommes, en un mot, à une foule de monstrés semblances. Parmi tous ces êtres, les uns étaient construits de manière qu'ils semblaient êtres doués de l'intelligence: ceux-là conservèrent la vie, et propagèrent leur espèce, mais ceux auxquels l'organe de la vie manquait, retombèrent dans le chaos, d'ou ils étaient sortis." ("Histoire de la Medécine," par Kurt Sprengel, vol. i. p. 249.) Sprengel gives the following references:-Aristotle, Physic Lib. ii., c. 4 , p. $465 .$, c. 8 , p. 470. Owing to my distance from a public library I have not hitherto had an opport:1nity of referring to Aristotle; but as Prof. Jevons is more favourably circumstanced, I hope he will consult the original, and if he finds anything which throws further light upon this interesting question, that he will report it to your readers.

Although, as Prof. Jevons remarks, the introduction of the notion of chance is erroneous, the speculation shows how thoroughly the Greek Atomists had banished from their explanations of phenomena all reference to first and final causes, anticipating in this respect the modern conception of science. I cannot deny myself the pleasure of quoting the weighty judgment of Bacon upon this point:- "And therefore the natural philosophies of Democritus and others," says Bacon, "who allow no God or mind in the frame of things, but attribute the structure of the universe to infinite essays and trials of nature, or what they call fate or fortune, and assigned the causes of particular things to the necessity of matter without any intermixture of final causes, seem, so far as we can judge from the remains of their philosophy, much more solid, and to have gone deeper into nature, with regard to physical canses, than the philosophy of Aristotle or Plato; and this only because they never meddled with final canses, which the others were perpetually inculcating." (Ad. vancement of Learning, Book iii. chap. iv.)

Waterfoot, March 8

JAMES ROSS

\section{ARISTOTLE}

IT is interesting, as Mr. Jevons says, to observe such traces as are to be found in history of theories more or less anticipating the principle of natural selection. But if the instance he cites from Maupertuis fairly represents the last century in this matter, it is chiefly of interest as showing what a little way it is postible to travel on certain roads in twenty-two centuries: for Aristotle discusses the same theory in his "Physics" (ii. 8), and appears to attribute it to Empedocles. "It may be a question," he says, "whether physiological effects which seem to be due to final causes are not really accidental. An organism survived, we may suppose, if it happened to be as a whole constituted in a suitable manner; that is, in a manner in which it would have been constituted by design; organisms otherwise constituted

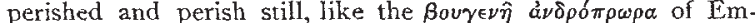
pedocles." Now, except that his monsiers are certainly not quite so monsirous, I do not see that the "Flattener of the Earth" gets beyond that. At any rate he lags behind Lucretius, who adopts the same theory of "discriminative destruction" (v. 837-877), but app'ies it, as Mr. Munro points out (on line 855 ), not merely to monsters but to " regularly organised creatures," either nit so gifted as to protect themselves or not so valuable as to be protected by man.

This is, as far as it goes, a theory of natural selection. It is a theory of the survival of the fit, absolutely; but not being a theory of the preponderant survival of the fitter, and not taking adequate account of inheritance, it is not a theory of evolution. Indeed, though Lucretius recognised a constant change in the conditioning circumstances, and therefore in the organisms conditioned $(828-836)$, it was to account for the stability of species that he called in natural selection and not to give a clue to the laws of their variation. That is the direction in which there must have been most room for progress; and traces of such progress may be to be found. Has Mr. Jevons tried Gassendi ?

Hadley, Middlesex
C. J. MONRO 